\title{
A dramatic landscape
}

Final pre-publication manuscript of Chapter 1 "A dramatic landscape" in book "The drama of conservation - the history of Pureora Forest, New Zealand".

See the book for definitive version.

Citation:

Lowe, D.J., King, C.M. 2015. A dramatic landscape. In: King, C.M., Gaukrodger, D.J., Ritchie, N.A. (eds), The Drama of Conservation - The History of Pureora Forest, New Zealand. Springer, Berlin, and New Zealand Dept. of Conservation, Wellington, pp.1-17. [DOI 10.1007/978-3-319-18410-4_1]

Available for purchase from New Zealand Department of Conservation or Springer http://www.springer.com/gp/book/9783319184098\#aboutBook 


\title{
A Dramatic Landscape
}

\author{
D. J. Lowe and C. M. King
}

School of Science, University of Waikato, Private Bag 3105, Hamilton 3240, New Zealand d.lowe@waikato.ac.nz

\section{Abstract}

This chapter introduces the story of Pureora Forest Park (PFP), in the central North Island, New Zealand, by describing the extremely violent Taupo eruption of c. AD 232 and its consequences for the surrounding forests and mountains. It gives a broad-scale local geological history, detailing the origins of some important local sedimentary rocks and landforms with a bearing on the story, including limestone caverns and coal deposits. It describes the location of the future PFP on the western edge of the Taupo Volcanic Zone, and how the history of volcanic activity, together with erosion, have determined much of the character of its landscape, the radial drainage pattern and deep entrenchment of its rivers, the distribution of its vegetation, and its long isolation from human access and permanent settlement.

\section{Contents}

1.1 Introduction $\quad 2$

1.2 The Taupo Eruption 2

1.3 Geological History of the West Taupo Area 6

1.4 Pureora and Titiraupenga 9

1.5 Rivers and Valleys $\quad 12$

1.6 How Geography Helps Determine History 13

$\begin{array}{ll}1.7 \text { References } & 14\end{array}$

Box 1.1 Volcanic events and deposits in the central North Island $\quad 18$ Terminology 18

Explosive eruptions and products: a summary 18

Taupo eruption, its products and impacts 20

Explanation of Fig. 1.4 [Taupo eruption sequence) 21

Box 1.2 Climate and soils of the Pureora area 21

Climate 21

Soils 22

Keywords

Lake Taupo; Pureora; Titiraupenga; Taupo eruption; Pyroclastic flow; Taupo ignimbrite;

Plinian eruptions; Geology of west Taupo; Whakamaru ignimbrite; break-out floods;

carbonised forest; Pumice soils; Pureora climate 


\subsection{Introduction}

Lake Taupo (623 km² surface area, $357 \mathrm{~m}$ above sea level, and up to $185 \mathrm{~m}$ deep) is a justly famous mecca for tourists, boat-owners and trout anglers in the centre of New Zealand's North Island. It is the largest body of freshwater in Australasia, cradled by green mountains on both east and west, and the permanent snows of Tongariro National Park to the south. One of the earliest views of it, painted by Ferdinand von Hochstetter in 1859 (Hochstetter 1867)[11], illustrates well the appeal of this majestic landscape, still as striking as it was in Hochstetter's day (Fig 1.1).

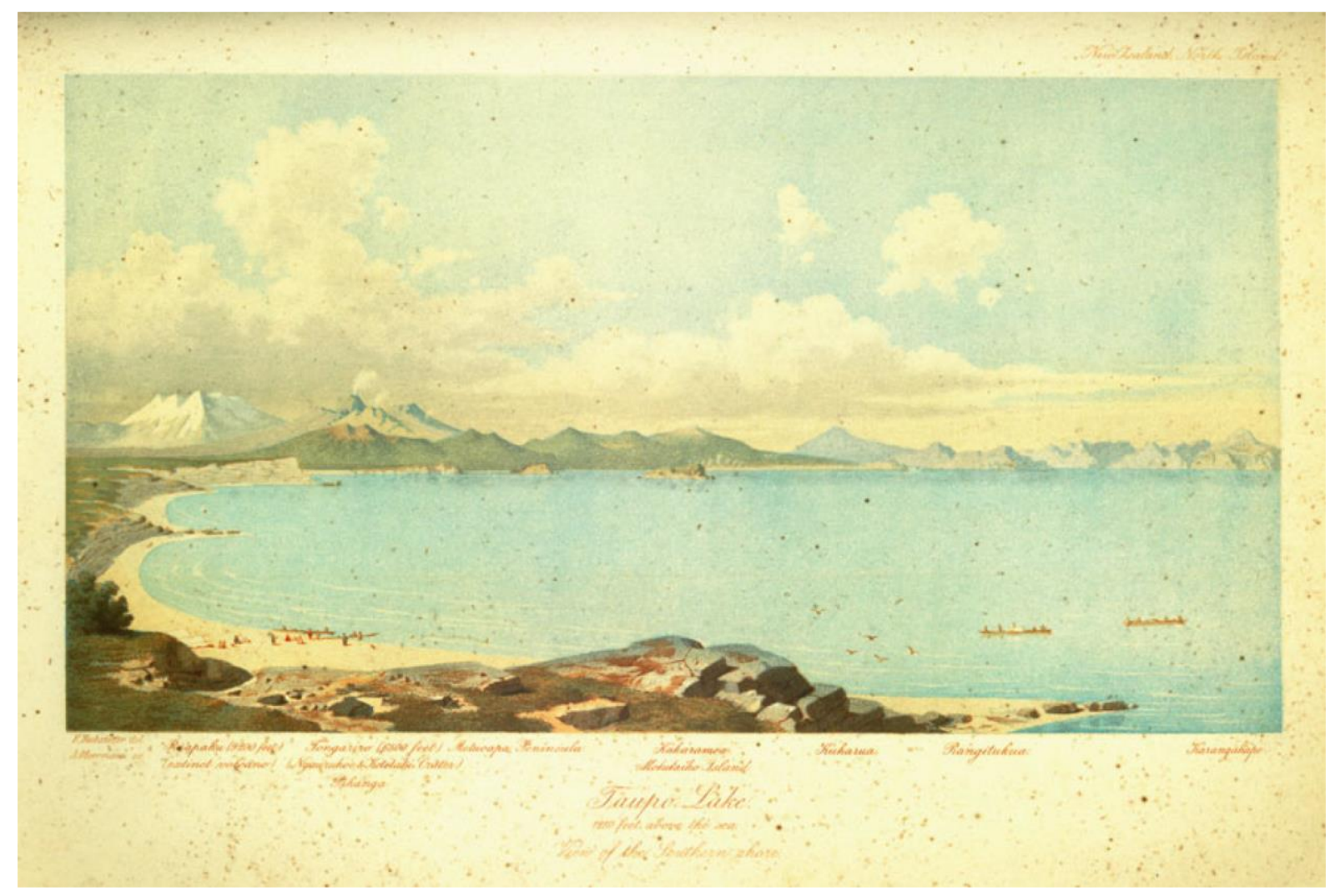

Fig. 1.1 Lake Taupo viewed across to the southern shore in 1859. Prominent peaks: Ruapehu, Tongariro, Ngauruhoe (left); Pihanga (centre); and Karangahape (far right). From Hochstetter [11: 364], courtesy of University of Auckland Libraries, Early New Zealand Books Collection

The scene looks peaceful, but is deceptive. Taupo is also the most frequently active and productive rhyolite volcano on Earth (Wilson and Leonard 2015; Wilson et al. 2009) [44, 50]. The story of this beautiful but potentially dangerous place provides a dramatic introduction to the story of Pureora Forest.

\subsection{The Taupo Eruption}

About AD 232, long before human explorers discovered New Zealand, the Taupo volcano produced the most violent volcanic eruption known in the world in the last 5000 years 
(Hogg et al. 2012; Wilson and Walker 1985) [12, 46]. Towards the climax of the eruption, a towering eruption column, described by volcanologists until recently as 'ultraplinian' (Walker 1980) [41] but now simply 'plinian' (Houghton et al. 2015) [14], threw around 23 cubic kilometres of loose volcanic material high into the atmosphere and stratosphere, about 35-40 km above ground (Houghton et al. 2015) [14] (about twice as high as the eruption column of Mt St Helens in 1980). Ash was blown eastwards across the North Island, well beyond Hawke's Bay and over the Pacific Ocean.

The column then collapsed catastrophically back to earth, generating deadly pyroclastic flows during the eruption's final climactic and most destructive phase (Fig 1.2). Their burning, broiling fronts radiated outwards from the vent area at speeds exceeding 150 $\mathrm{m} / \mathrm{sec}(540 \mathrm{~km} / \mathrm{h})$ for about $80 \mathrm{~km}( \pm 10 \mathrm{~km})$ in all directions, and the flow stopped only when the material ran out. The flows covered about $20,000 \mathrm{~km}^{2}$ of surrounding country in less than seven minutes (Wilson and Walker 1985) [45].

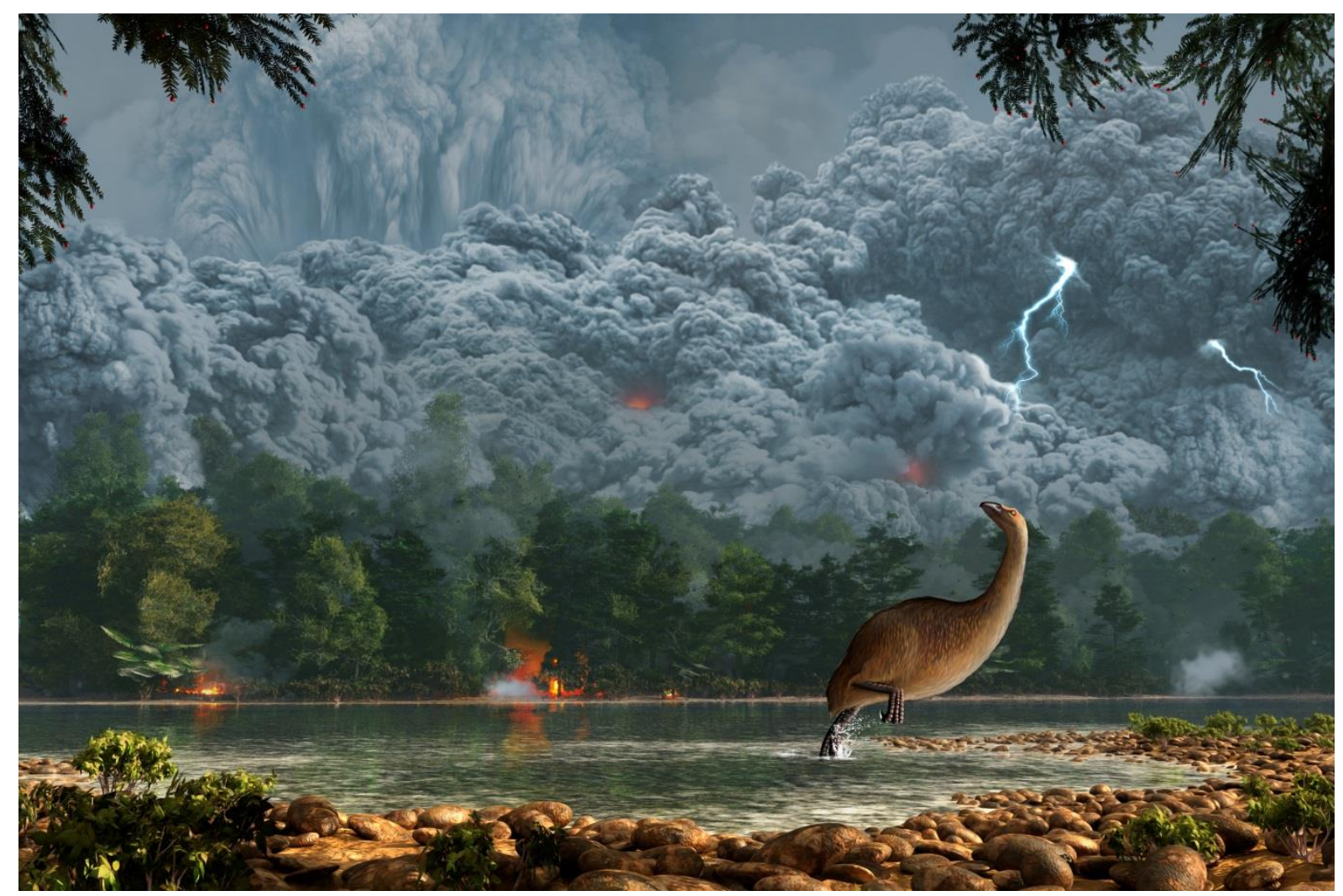

Fig. 1.2 Artist's impression of the catastrophic final phase of the Taupo eruption of c. AD 232. The towering eruption column in the background (at Lake Taupo) is collapsing and generating the roiling 'clouds' of very hot gas, ash, pumice, crystals, and rock fragments racing radially outward at high speed across the land as a ground-hugging pyroclastic flow, engulfing forests and animals in its path. The resulting non-welded ignimbrite deposit covers an area surrounding Lake Taupo to a radius of about 80 km (Wilson 1985) [45]. Painting by Mark Garlick, specially commissioned for this book by David J. Lowe and Adrian Pittari, School of Science, University of Waikato 


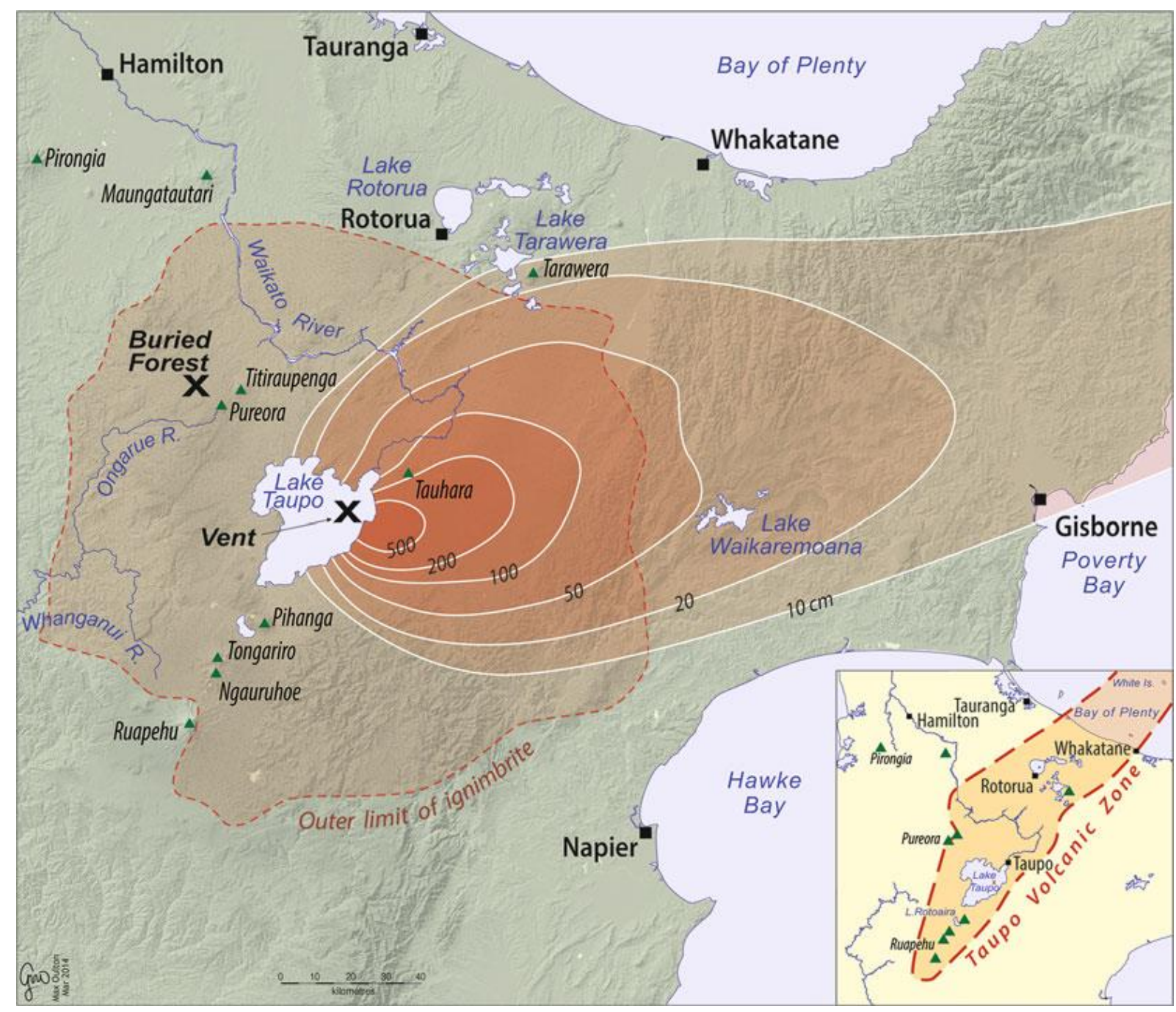

Fig. 1.3 The consequences of the powerful Taupo eruption of c. AD 232, showing the position of the vent, now submerged under Lake Taupo; the area covered by ashfall to a depth of $10 \mathrm{~cm}$ or more, with thickness contours (isopachs) in centimetres; the final extent of deposits from the extremely energetic pyroclastic flow, which spread a layer of loose ignimbrite across $20,000 \mathrm{~km}^{2}$, covering all neighbouring peaks except Ruapehu in the southwest; and the position of the Buried Forest at Pureora. Redrawn by Max Oulton from Wilson and Leonard (2015: 171) [44]. NB: by convention, the bay itself is Hawke Bay, whereas the adjacent land is the Hawke's or Hawkes Bay region. Inset: Map of the Taupo Volcanic Zone (TVZ), extending from south of Ruapehu to White Island (Whakaari). The TVZ includes many volcanoes and hot springs and several geysers. Redrawn by Max Oulton from Wilson and Leonard (2015: 168) [44].

All the surrounding mountains - the entire Hauhungaroa and Kaimanawa Ranges, the volcanic peaks of Pureora, Titiraupenga, and Tongariro, and much of the adjacent area except southwest Ruapehu - were blanketed in multiple suffocating layers representing the products of successive phases of the eruption (Figs. 1.3 and 1.4). The total output from the volcano through all stages of the eruption was about 105 cubic kilometres of loose volcanic material. For some more detailed technical explanations, see Box 1.1. 
After the c. AD 232 eruption, Lake Taupo refilled over a period of about 15 to 40 years to a level some 30-40 m higher than today's (about where Taupo town now stands, at $400 \mathrm{~m}$ above sea level), held back by a temporary dam. When it collapsed, about twenty cubic kilometres of water was suddenly released down the Waikato River, an equivalent volume to that of the Mississippi River in flood (Manville et al. 1999) [22].

Break-out flood deposits from this event can be traced along the Waikato River valley for up to $220 \mathrm{~km}$ downstream from Lake Taupo, burying large areas that were otherwise little affected by the eruption. Parts of the modern city of Hamilton are built on the break-out flood deposits alongside the present Waikato River. Other North Island rivers, including the Whanganui, Rangitaiki, Mohaka, and Ngaruroro, were choked with fall deposits and Taupo ignimbrite materials (Manville et al. 2007; 2009) [24, 25].

All the original forest, about one cubic kilometre of timber, standing within about $80 \mathrm{~km}$ of the vent (the zone of Taupo ignimbrite emplacement), was almost instantly engulfed and incinerated (Hudspith et al. 2010) [15], and the carbonized remains buried under a temporarily sterilised duvet (Fig. 1.5). Only a few remnants of pre-eruption forest survive, fortunately protected by rocky outcrops, such as the patch of silver beech that still grows in a gorge in the headwaters of the Mangatu Stream, in the Waihaha Forest.
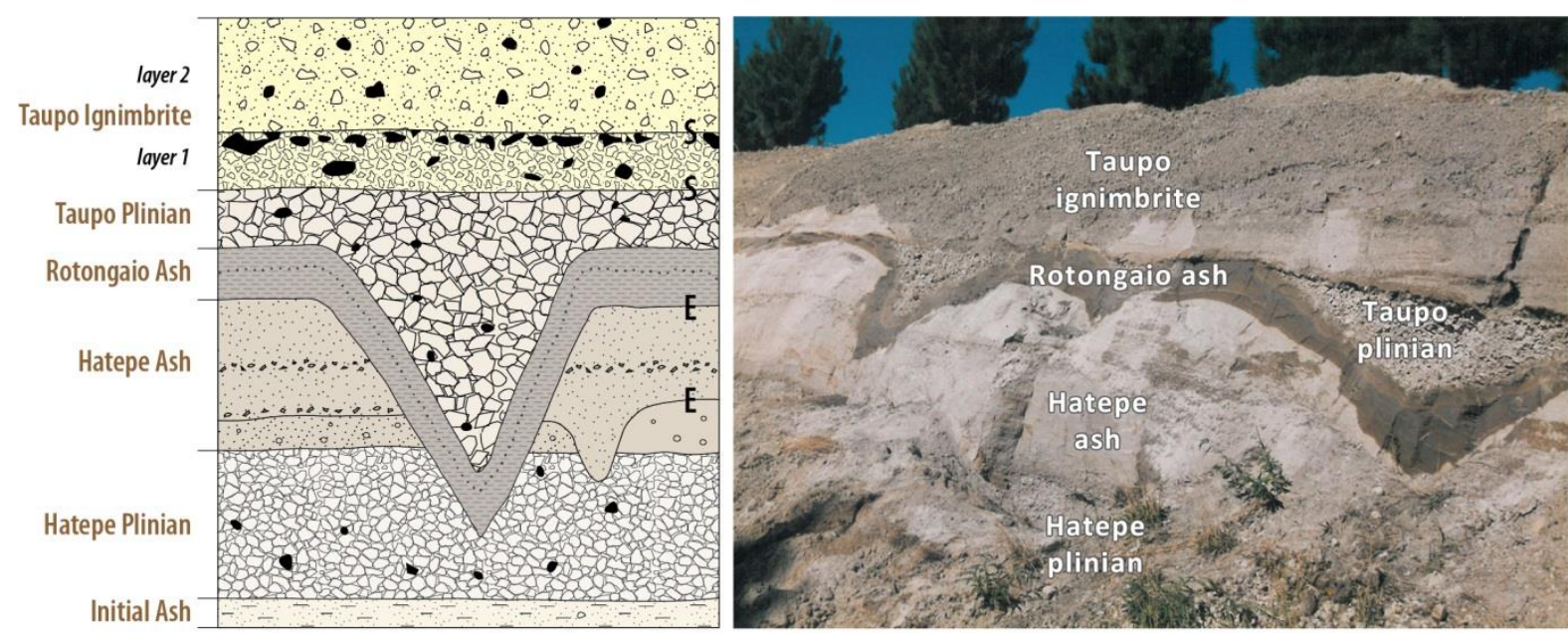

Fig. 1.4 Six of the seven distinct phases of the Taupo eruption are shown in this section, exposed in a forest road cutting. The first five units (Initial Ash, not deposited at this site, was followed by Hatepe Plinian, Hatepe Ash, Rotongaio Ash, and Taupo Plinian) are all fall deposits. Taupo Ignimbrite was deposited at the climax of the eruption from a hot, fast-moving, ground-hugging pyroclastic flow. The Vshaped incisions into the Hatepe Ash mark a break of up to c. 3 weeks when torrential floods from intense rain carved gullies into the soft surface (denoted by ' $E$ '), into which the 'muddy' Rotongaio Ash was deposited. The emplacement of Taupo ignimbrite stripped the top of the Taupo plinian deposits, resulting in a 'planed' appearance (marked by ' $\mathrm{S}$ '). For further details see Box 1.1, p.21. Diagram redrawn by Max Oulton after Houghton \& Wilson (1986: 59) [13]; photo by David J. Lowe 


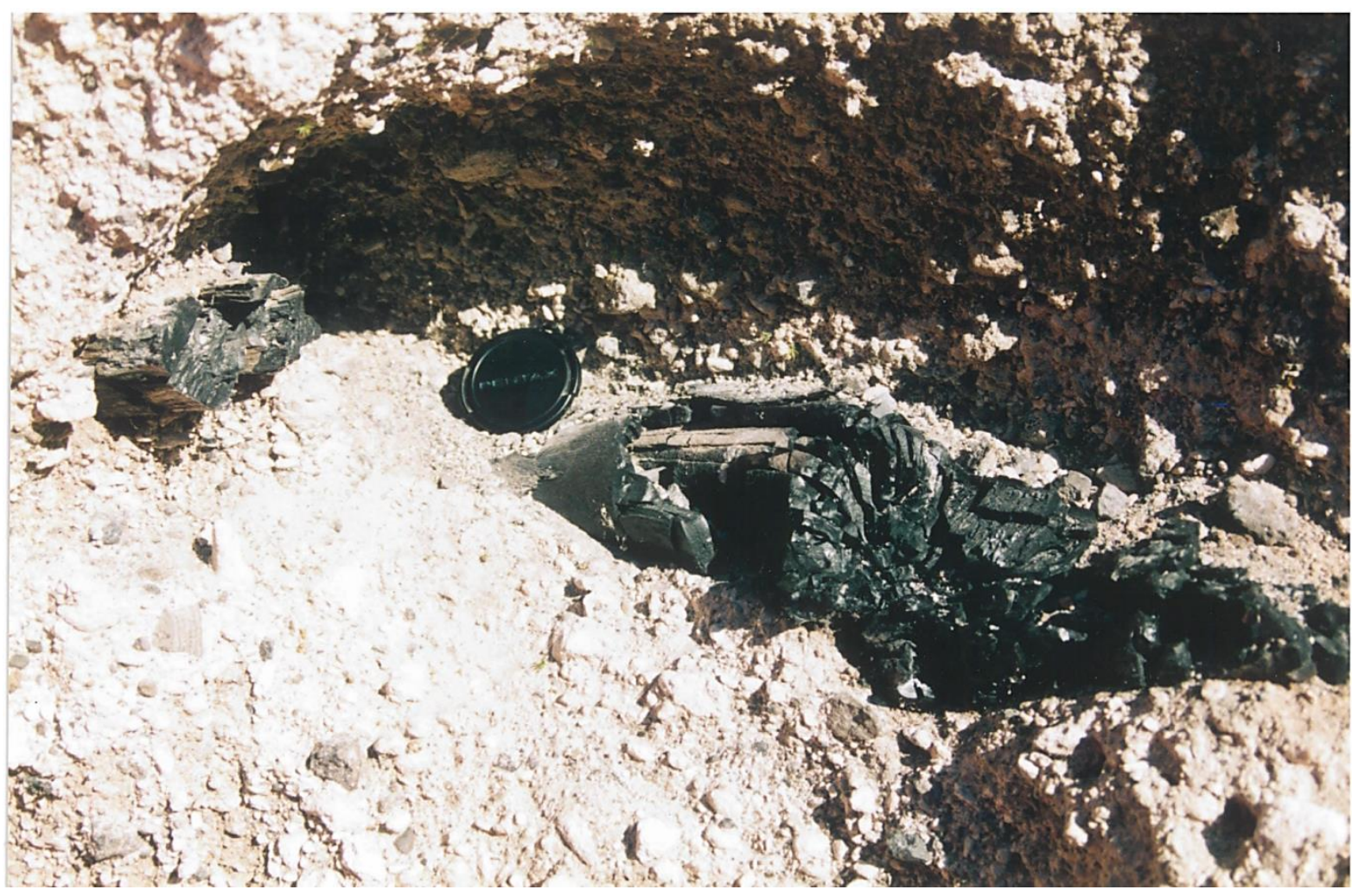

Fig. 1.5 Two charred logs lying within pumiceous Taupo ignimbrite at a site near Wairakei. Such carbonized logs have been measured at up to $1 \mathrm{~m}$ in diameter and $5 \mathrm{~m}$ in length. The trees were broken off by the pyroclastic flow or preceding blast, and then incorporated into the flow. Their pattern of orientation radially around the eruption vent provided a means of deducing its position (Froggatt et al. 1981) [7]. The logs were probably charred in situ at temperatures between at least $270{ }^{\circ}$ and $400^{\circ} \mathrm{C}$ (Hudspith et al. 2010) [15]. Lens cap $5 \mathrm{~cm}$ in diameter. David J. Lowe

From about $80 \mathrm{~km}$ to about $170 \mathrm{~km}$ east from the eruption centre, ash-fall deposits were thinner and cold, and generally caused progressively less devastating damage. Fires started during the eruption burned for decades (Wilmshurst and McGlone 1996) [43]. The collective effects of the eruption rendered uninhabitable an area now occupied by $>200,000$ people.

Dramatic as it was, the Taupo eruption was only the latest act in a very long play. Prolonged volcanic activity over thousands of years has left its mark on the modern composition and distribution of the soils and on the forests they support. Those earlier events help to explain much about the contemporary environment in this area.

\subsection{Geological History of the West Taupo Area}

The basement layers of sediments that now form greywacke rocks (mostly hard sandstone) under the Hauhungaroas were laid down on the sea bed in the Late Jurassic, about 155 million years ago (Mya), and represent complex deep marine deposits added onto the 
eastern Gondwana margin (Leonard et al. 2010) [19]. In places, such as at the base of the Waihuka Falls, fossickers can still find rare fossil shells as evidence of that distant time.

The sediments were uplifted after deposition, and altered by tectonic movements to form part of Zealandia, a large chunk of new land on the edge of the ancient continent, thickly covered with huge forests and peat swamps. Then, starting about 80 Mya, further tectonic movements split Zealandia off into a substantial continental fragment that slowly drifted eastward into permanent isolation in the southwest Pacific (Sutherland and King 2015) [36].

Widespread faulting across this ancient landscape in the mid-Tertiary period (c. 40 to 30 Mya) formed basins which became filled with sediments shed from adjacent higher ground. River flood plains and peaty swamps developed, thickly covered with forest and swamp vegetation. When the land subsided, the old land surface was flooded by the sea, and then buried and compressed by accumulating marine sediments that eventually formed mudstones, sandstones, and limestones (Edbrooke 2005; King 2015) [5, 16].

These sedimentary deposits play a less dramatic role in this story than that of the volcanoes, but still an important one. The limestones were corroded into the cave systems of the Waitomo district, which preserve a veritable zoo representing the prehistoric fauna that once roamed the central North Island forests, including many extinct birds and invertebrates (Worthy and Holdaway 2002) [51]. The remains of the ancient swamps eventually became coal, and are preserved as the Waikato Coal Measures (Sherwood and Edbrooke 2015) [34]. In their time they were an essential resource for steam-driven engines and mills, and were mined during the $20^{\text {th }}$ Century at Mangapehi and Benneydale (Chap. 5).

About 25 Mya, the Australian-Pacific convergent plate margin began to develop, and new tectonic movements began to rearrange the geography of Zealandia. The greywacke basement rocks were uplifted to form the backbones of both main islands, now exposed in the Pureora area as alternating bands of sandstones and mudstones, split and bounded by northeast-southwest trending faults. The Rangitoto Range to the north of Pureora village, and part of the Hauhungaroa Range, which runs more or less continuously for some $70 \mathrm{~km}$ north to south along the west side of Lake Taupo (Fig. 0.1 in Preface), are both examples of uplifted, fault-bound blocks of greywacke rocks (Edbrooke 2005; Leonard et al. 2010) [5, 19]. Large areas of these ranges have been overlaid by the more recent products of cataclysmic volcanic eruptions (Box 1.1, p. 17).

From about 1.6 million to about 900,000 years ago, successive explosive eruptions generated voluminous pyroclastic flows from the Mangakino volcano, and from the Whakamaru volcano around 350,000 years ago (Box 1.1). Very hot, fast-moving pumice-rich material, buoyed by superheated gases, raced across the landscape. Where the deposits were hottest and thickest, the pyroclastic material hardened into sheets of welded ignimbrite. They have since eroded to form distinctive landscapes with prominent cliffs, often with vertical joints, as seen for example along the Mangakahu Valley (Fig. 1.6). A cap 
of densely welded ignimbrite remains on the nearby flat-topped Hikurangi, $10 \mathrm{~km}$ northeast of Taumarunui, giving an effect described by Hochstetter (Chap. 6) as "the top appearing as if cut smooth with a knife" (Hochstetter 1867: 355) [11] (Fig. 1.7).

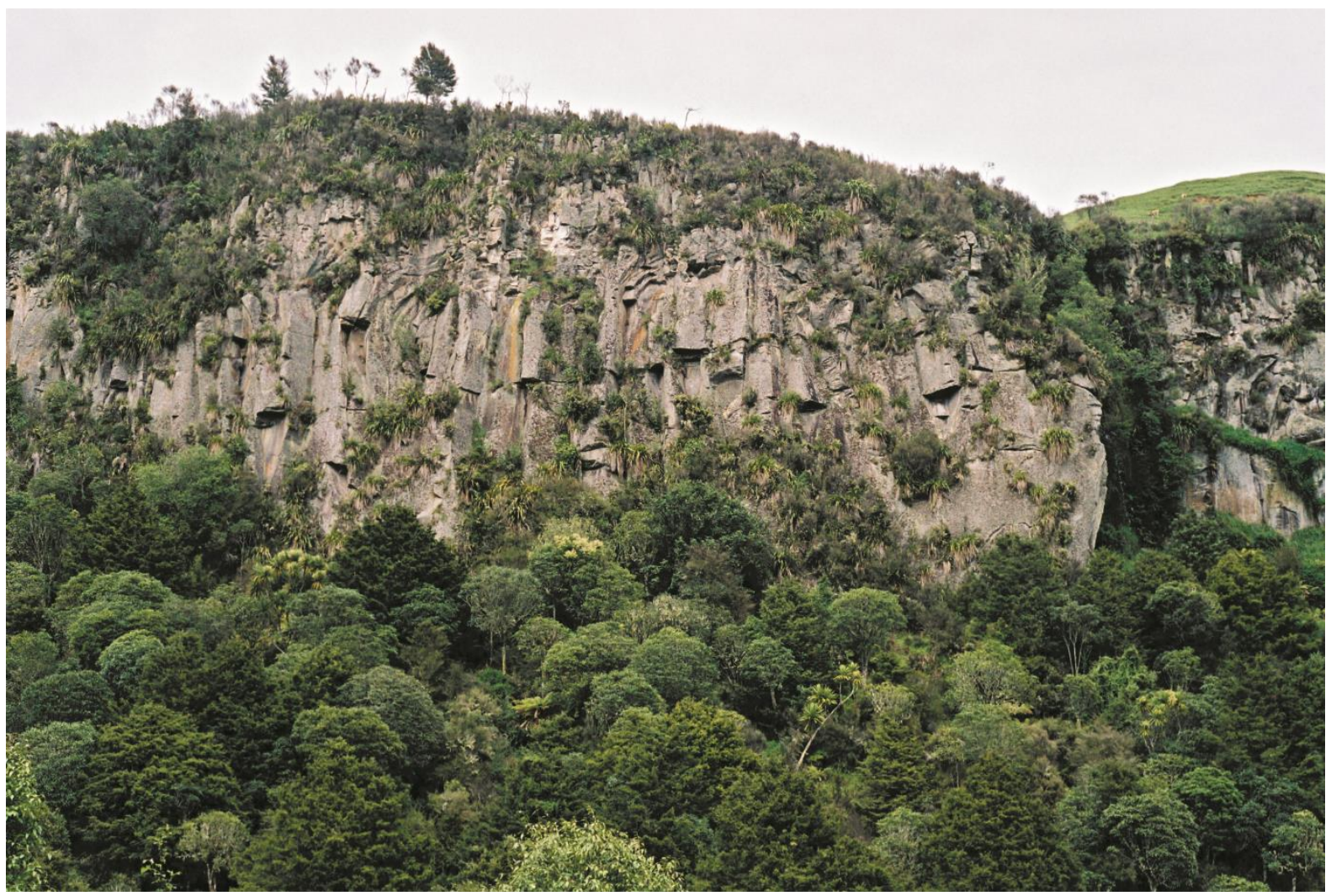

Fig. 1.6 A welded (hard) ignimbrite of the Whakamaru Group, erupted about 350,000 years ago as a pyroclastic flow from Whakamaru caldera volcano, with well developed vertical and subhorizontal cooling joints, exposed in the Mangakahu Valley east of Ongarue. Photo from Edbrooke (2005: 40) [5] with permission: GNS Science image 140102 (c) Steve Edbrooke, GNS Science

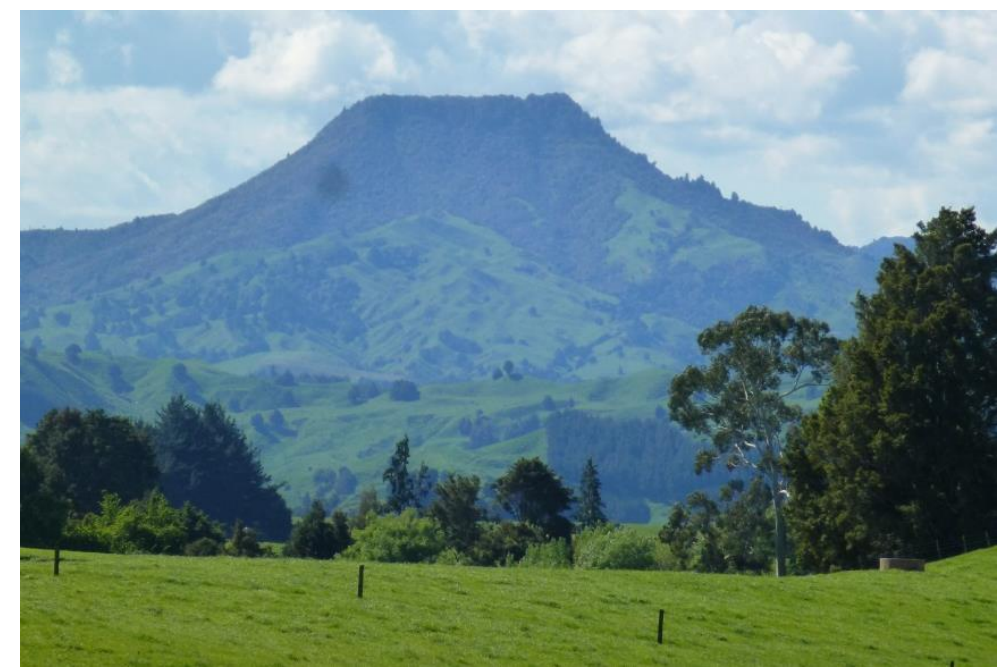

Fig. 1.7 Hikurangi, an eroded remnant of a former landscape, is capped by a now-welded ignimbrite erupted as a pyroclastic flow from the Mangakino caldera 1.23 Mya (Edbrooke 2005) [5]. C. M. King 
About 25,400 years ago, the Taupo volcano produced the Oruanui/Kawakawa 'supereruption' event [49]. It was an earlier and much larger event than the better-known Taupo eruption, centred on the wide northern part of modern-day Lake Taupo (including Western Bay). It generated about 1170 cubic kilometres of loose volcanic material, distributed as pyroclastic flow deposits from the caldera, and as fall deposits that were blown at least $1500 \mathrm{~km}$ beyond the New Zealand islands (Wilson 2001) [48]. The magma chamber producing all this material emptied, leaving the overlying section of the Earth's crust unsupported. It collapsed into a massive near-circular caldera $35 \mathrm{~km}$ across (a caldera is a large-scale ground collapse feature resulting from instability caused by the eruption of magma) (Smith et al. 2012) [35].

Much of the accumulated volcaniclastic debris from this eruption washed down the ancestral Waikato River and blocked its then-normal flow north into the Firth of Thames (Manville and Wilson 2004) [23]. Around 22,000 years ago, the river diverted sharply westwards, to reach the Tasman Sea via its present mouth at Port Waikato. From its junction with State Highway (SH) 1, SH 29 runs toward Tauranga through the old, choked-off valley of the ancestral Waikato River. Modern vehicles drive across its old bed, flanked on both sides by the tops of welded ignimbrite rock walls whose feet, which once stood at the river side, are now buried deep below the surface.

Of the succeeding 28 eruptions, all but three within the last 12,000 years, the Taupo eruption is by far the most famous. It formed a second, smaller caldera within the older Oruanui/Kawakawa caldera [47]. The northern part of the lake now occupies both of them.

\subsection{Pureora and Titiraupenga}

Pureora $(1165 \mathrm{~m})$ and Titiraupenga $(1042 \mathrm{~m})$ are the two principal volcanic peaks defining the skyline of the Hauhungaroa Range along the west shore of Lake Taupo, visible from both east and west (Fig. 1.8). They are andesitic volcanoes (Froude and Cole 1985) [8], aged about 1.6 and 1.9 Mya, respectively (Graham et al. 1995) [9].

Titiraupenga is a dominant landmark, distinguished by a great spire of naked rock at its summit (a plug marking the position of the main volcanic vent). Just a few kilometres to the southwest is the gently sloping cone of Pureora. The characters of these mountains and their surrounding landscape have been largely determined by the prolonged and recent volcanic activity of the area, not just from the Taupo caldera, and from on-going erosion as well. 


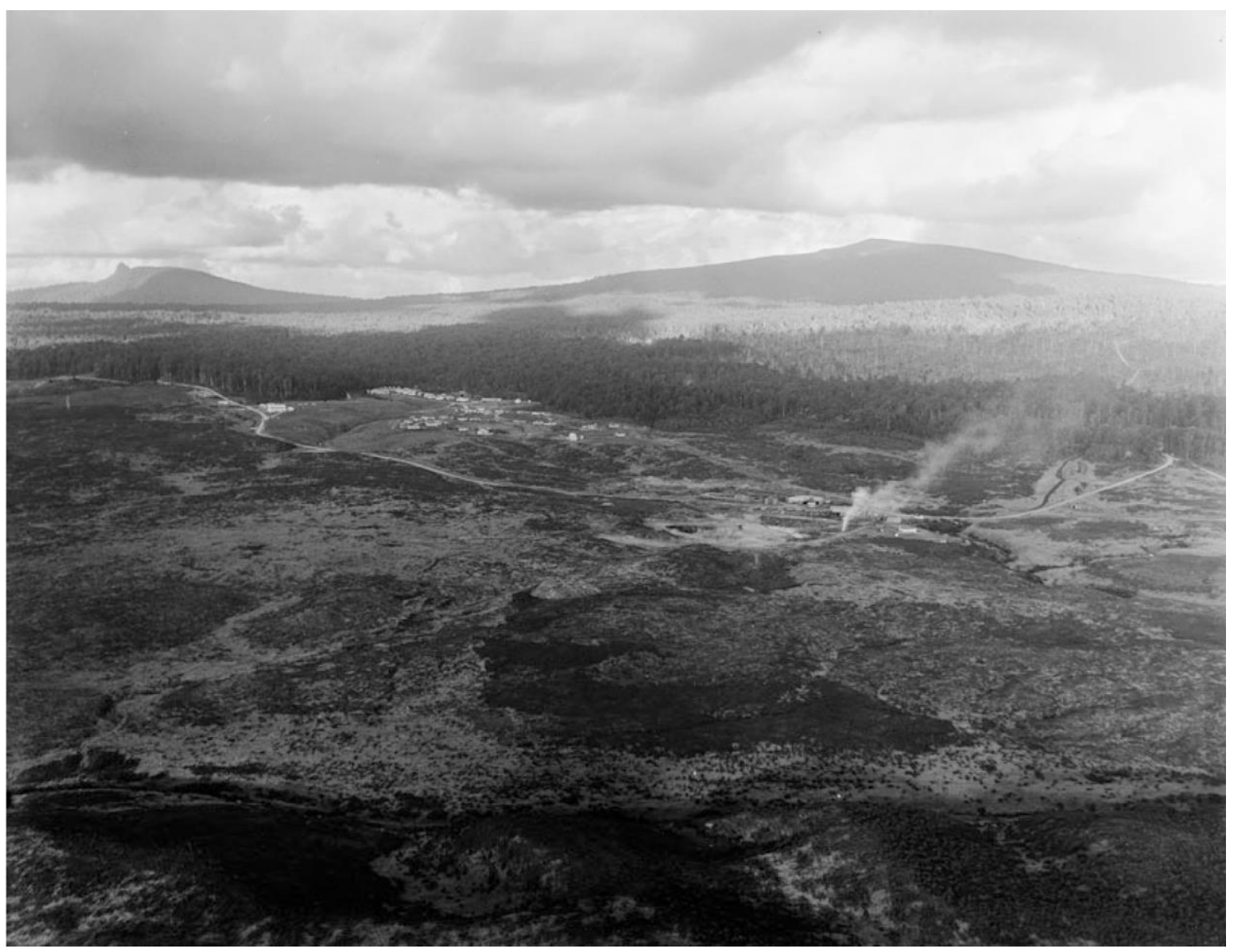

Fig. 1.8 Pureora Forest, including Titiraupenga (left) and Pureora (right) mountains on the skyline, and the two steam-driven sawmills at the western end of the village, April 1951 (see Fig. 8.5). View ESE across the Ruapehu District. Whites Aviation photograph WA-27381-F. Alexander Turnbull Library, Wellington, New Zealand

These peaks are encircled by skirts of welded rhyolitic ignimbrite derived from both the Mangakino caldera (dating from c. 1.6 Mya to c. 0.9 Mya) and the Whakamaru caldera (dating to c. 350,000 years ago) (Leonard et al. 2010) [19]. These volcanic materials, explosively poured and flung over the much more ancient (c. 150 Mya) greywacke basement, have been carved by river erosion and other geomorphic processes, including headward erosion and mass movement, into steep gullies radiating in all directions from the peaks (Fig. 1.9). All along the roads around the peaks and Lake Taupo, sheer cliffs, crags of solid volcanic rock, and exposed layers of ash and both welded and non-welded ignimbrite, bear witness to the violent past of this area.

The young soils developed from this surface material, interacting with the cool, wet climate of the central high country (Box 1.2, p. 21), eventually helped to influence the patterns of the vegetation that repeatedly re-clothed the devastated land. Young soils on loose materials are also very vulnerable on exposure to erosion, which easily leads to damage requiring expensive repairs, as on the track to the summit of Pureora (Fig 1.10). 


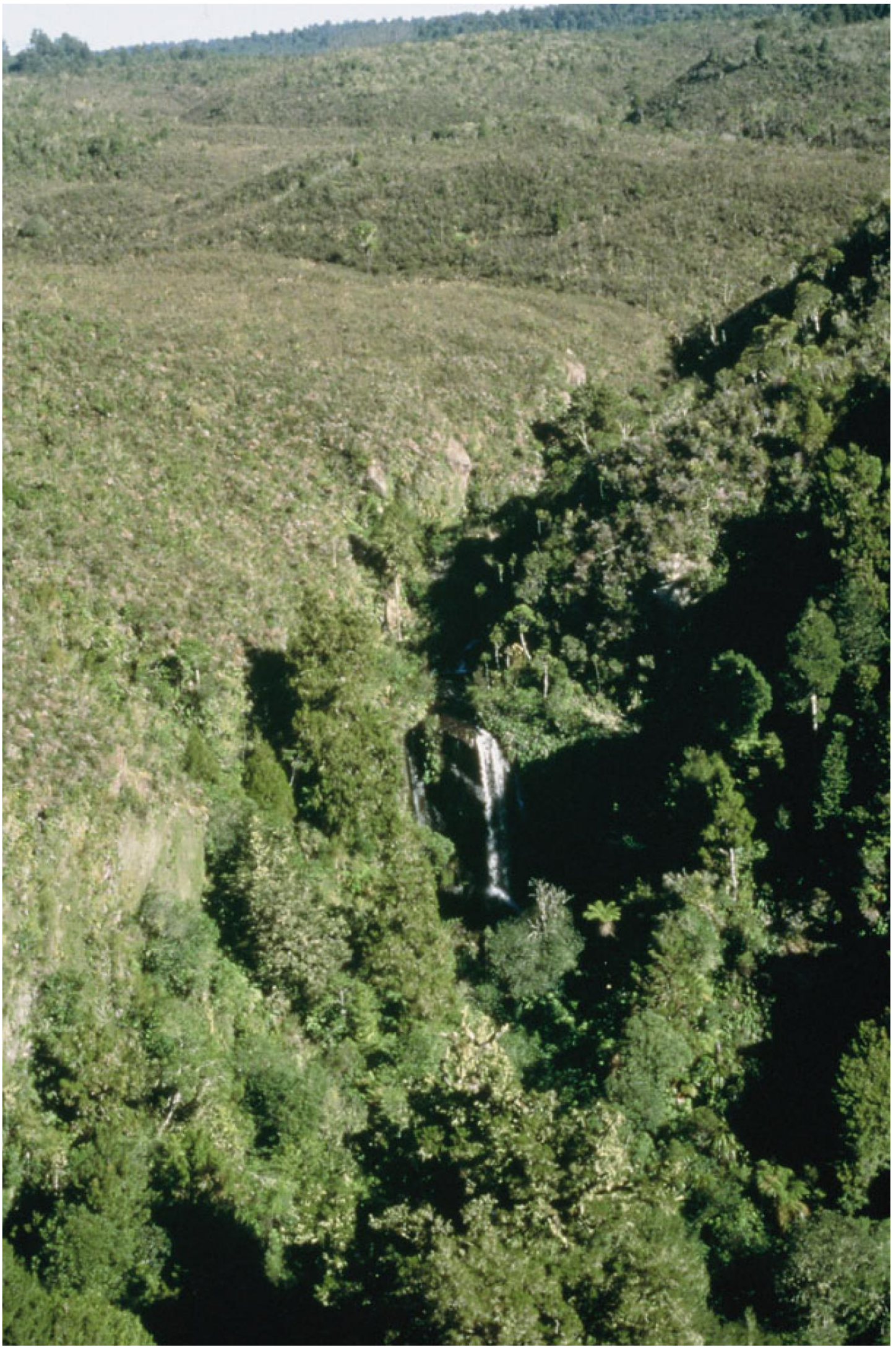

Fig. 1.9 A typical landscape in Pureora Forest Park. Thick forest in the Waipapa Ecological Area surrounds a waterfall cascading over the edge of an ancient welded ignimbrite sheet. Another sheet of ignimbrite lies above the river level. Crown Copyright, Department of Conservation Te Papa Atawhai (1995). Photographer: John Mason. DOC image library 10067771 


\subsection{Rivers and Valleys}

The geographic centre of the North Island lies on the Hauhungaroa Range, not far from Pureora village (Fig. 14.1). So the mountains of the park are as far as it is possible to be from any coast, which is why they provide the upper watersheds of some of New Zealand's most important rivers draining away in all directions. They have tended to develop a radial pattern of deeply incised gorges where they cross young pumice surfaces, and some have formed spectacular waterfalls where they spill over the edges of welded sheets of ignimbrite (Fig. 1.9).

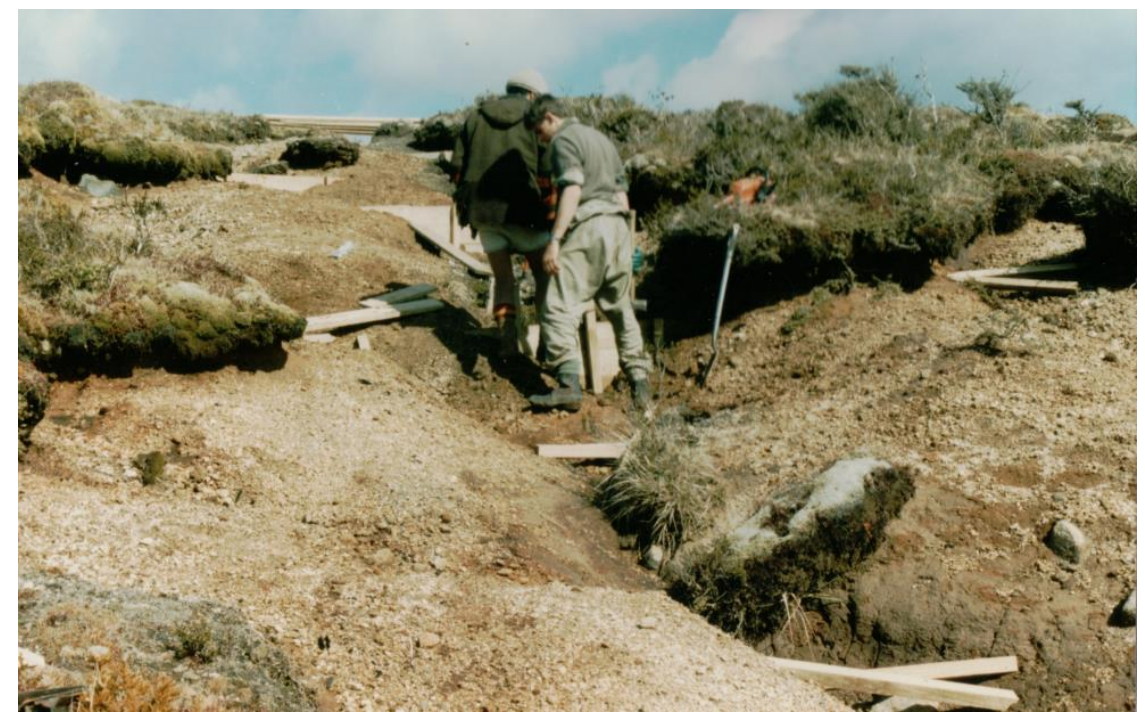

Fig. 1.10 Track repairs on Pureora summit. The pumice deposits covering the peak up to about $1 \mathrm{~m}$ deep are soft Taupo ignimbrite erupted c. AD 232. The very high energy release of the eruption enabled the ground-hugging, ignimbrite-generating pyroclastic flow to ascend $>1000 \mathrm{~m}$ to overtop Pureora (see Box 1.1). The weakly weathered loose pumice, once exposed and lacking vegetation cover, is very vulnerable to erosion by heavy rain and human traffic. Crown Copyright, Department of Conservation Te Papa Atawhai. Photographer: John Mason

North of Pureora village and SH 30, along the two parallel greywacke ranges of Rangitoto and Pukeokahu, the main peaks are Rangitoto (862 m) and Ranginui (983 m), drained to the east by the Waipapa and other Waikato tributaries, and to the west by the headwaters of the Waipa River. Both the Waipa and Waikato then flow north, and join at Ngaruawahia.

All the ranges and both the older cones of Pureora and Titiraupenga were mantled with pumice deposits, including the Taupo ignimbrite, from the Taupo eruption (Fig 1.10).To the south of Pureora and Titiraupenga lies the main block of the Hauhungaroas (about $70 \mathrm{~km}$ north to south, and about $25 \mathrm{~km}$ east to west at their widest), sprawling square across the middle of the North Island between the east-west ribbons of SHs 30 and 41. 
The ridge and its highest point, Weraroa (1091 m), is the watershed between streams running down the steeper eastern face of the range, and those draining the broad rolling ridges of its western face. The eastern streams flow into Lake Taupo, and from there their waters join the Waikato River. The western streams have cut deep incisions on their way to join the Ongarue, Waimiha, and Okauaka Rivers, which are in turn important tributaries of the upper Whanganui River, which runs south through a steep-walled canyon.

To the southwest, semi-detached from the Hauhungaroas and forming a prominent cornerpeg to one of the more jagged stretches of the park boundary, is Tuhua, a visually impressive non-volcanic mountain. It was an important landmark for travellers, both for Maori hunters and for the nineteenth-century Pakeha explorers following Maori trails (Chap. 3 and 4).

The scenic qualities of this area deeply impressed early European visitors, none more so than the surveyor Laurence Cussen.

Probably in no part of New Zealand can be found landscape so varied and picturesque as may be seen in favourable weather from some of the lofty peaks in this part of the district. Viewed under the conditions in which I first saw it, it would be difficult to conceive of a landscape of greater variety and grandeur. It was at sunrise on a clear frosty morning toward the end of May, from the summit of Pureora, 3,800 feet above the sea, overlooking all the surrounding country. The high mountainous district to the south was covered with snow; Taupo Lake seemed to be spread out at our feet, its 425 square miles of clear mirror-like surface reflecting the shadows of the eastern hills and promontories of the lake, cast across it by the rising sun. .....To the north and east wound the valley of the Waikato River; along its course columns of steam arose from the hundreds of hot springs, fumaroles and puhias [sic] of the Taupo volcanic zone....To the southwest, at a distance of 98 miles, the snow-clad sugarloaf peak of Taranaki (Mount Egmont) reared its head high above the surrounding landscape (Cussen 1888: 319-320) [4].

Some decades before Cussen, Ernst Dieffenbach waxed lyrical about the scenic qualities of the Taupo area and its future potential as a tourist centre (Chap. 4). Dieffenbach was also an observant scientist, and was the first to record what the pumice-rich soils and layers of tephra he found meant about recent volcanic history in the area.

\subsection{How Geography Helps Determine History}

The crests of the west Taupo ranges reach only just over $1000 \mathrm{~m}$ above sea level, about 500 $\mathrm{m}$ above the surrounding valley bottoms and plains, and are not romantically rugged by New Zealand standards. But they are large enough to be intimidating, and the deeply dissected gorges surrounding them offer a considerable barrier to most forms of human transport. In early times, navigable rivers were few, so nearly all communication routes have 
always gone round the west Taupo ranges rather than over them. Travelling across them with a large, heavy load was virtually impossible.

The combination of Pureora's central location and its geography explain why it has always been a difficult place to access. That, plus the aftermath of the 1860-1864 Waikato War and the closure of the King Country (Chap. 4), deterred European exploration and exploitation for decades.

The north-south link provided by the North Island Main Trunk Railway line from Auckland to Wellington past the western flank of Ruapehu was long delayed by the need to bridge dozens of east-west gorges. It was not fully completed until 1908, after construction of some spectacular viaducts and the remarkable Raurimu Spiral. SH 4 from Te Kuiti to Ohakune via Mapiu, still a bush track in 1911, was not completed until 1928 (Brake and Cooke 1986) [2]. South of the Hauhungaroas, SH 41 started as a bulldozed track in 1942, and was still unsealed in 1960 (Anderson 2000: 51) [1]; the only east-west road through the future park across the ranges, SH 30, reached Benneydale from Te Kuiti in 1939, but was not connected through to Mangakino and Taupo until 1955 (Wilkes et al. 2011) [42]. SH 32, running north-south along the western bays of Lake Taupo, became a through road in the late 1960s (Fig. 0.1 in Preface).

Taken together, these factors help explain why so many of the critical events described in this book are surprisingly recent.

\subsection{References}

1 Anderson K (2000) Servicing caterpillar. CAS Publications, Taumarunui.

2 Brake T, Cooke R (1986) Bush track to highway. C \& S Publications, Taumarunui.

3 Briggs RM, Gifford MG, Moyle AR, et al. (1993) Geochemical zoning and eruptive mixing in ignimbrites from Mangakino volcano, Taupo Volcanic Zone, New Zealand. Journal of Volcanology and Geothermal Research 56, 175-203.

4 Cussen $L(1888)$ Notes on the physiography and geology of the King Country. Transactions of the New Zealand Institute 20, 316-332.

5 Edbrooke SW (2005) Geology of the Waikato area: geological map 4, scale 1: 250,000. Institute of Geological and Nuclear Sciences, Lower Hutt.

6 Francis P (1993) Volcanoes: a planetary perspective. Clarendon Press, Oxford.

7 Froggatt PC, Wilson CJN, Walker GPL (1981) Orientation of logs in the Taupo Ignimbrite as an indicator of flow direction and vent position. Geology 9, 109-111.

8 Froude DO, Cole JW (1985) Petrography, mineralogy and chemistry of Titiraupenga volcano, North Island, New Zealand. New Zealand Journal of Geology and Geophysics 28, 487-496.

9 Graham IJ, Cole JW, Briggs RM, et al. (1995) Petrology and petrogenesis of volcanic rocks from the Taupo Volcanic Zone: a review. Journal of Volcanology and Geothermal Research 68, 59-87. 
10 Hessell JW (1986) The climate of Pureora Forest. In Veale B and Innes JG (ed.), Ecological research in the central North Island volcanic plateau region. Forest Research Institute, Rotorua, p. 27.

11 von Hochstetter $F(1867)$ New Zealand, its physical geography, geology and natural history. J. G. Cotta, Stuttgart.

12 Hogg AG, Lowe DJ, Palmer J, et al. (2012) Revised calendar date for the Taupo eruption derived by ${ }^{14} \mathrm{C}$ wiggle-matching using a New Zealand kauri ${ }^{14} \mathrm{C}$ calibration data set. The Holocene 22, 439-449.

13 Houghton BF, Wilson CJN (1986) Explosive rhyolitic volcanism: the case studies of Mayor Island and Taupo volcanoes. New Zealand Geological Survey Record 12, 33-100.

14 Houghton BF, Carey RJ, Rosenberg MD (2015) The Taupo eruption: "Ill wind" blows the ultraplinian type event down to Plinian. Geology 42, 459-461.

15 Hudspith VA, Scott AC, Wilson CJN, et al. (2010) Charring of woods by volcanic processes: an example from the Taupo ignimbrite, New Zealand. Palaeogeography, Palaeoclimatology, Palaeoecology 291, 40-51.

16 King P (2015) From source to sink. In Graham IJ (ed.), A continent on the move, 2nd edition. Geoscience Society of New Zealand, Miscellaneous Publication 141, pp. 132135.

17 Lee JM, Bland KJ, Townsend DB, et al. (2011) Geology of the Hawke's Bay area: geological map 8, scale 1: 250,000. Institute of Geological and Nuclear Sciences, Lower Hutt.

18 Leigh AH, Clegg SE (1989) Maniapoto District Wild Animal Management Plan, 1989 to 1999. Department of Conservation, Hamilton.

19 Leonard GS, Begg JG, Wilson CNJ (2010) Geology of the Rotorua area: geological map 5, scale 1: 250,000. Institute of Geological and Nuclear Sciences, Lower Hutt.

20 Lowe DJ, de Lange WP (2000) Volcano-meteorological tsunamis, the c. AD 200 Taupo eruption (New Zealand) and the possibility of a global tsunami. The Holocene 10, 401-407.

21 Lowe DJ, Newnham RM, McCraw JD (2002) Volcanism and early Maori society in New Zealand. In Torrence R and Grattan J (ed.), Natural disasters and cultural change. Routledge, London, pp. 126-161.

22 Manville V, White JDL, Houghton BF, et al. (1999) Paleohydrology and sedimentology of a post-1.8 ka breakout flood from intracaldera Lake Taupo, North Island, New Zealand. Geological Society of America Bulletin 111, 1435-1447.

23 Manville V, Wilson CJN (2004) The 26.5 ka Oruanui eruption, New Zealand: a review of the roles of volcanism and climate in the post-eruptive sedimentary response. New Zealand Journal of Geology and Geophysics 47, 525-547.

24 Manville V, Hodgson KA, Nairn IA (2007) A review of break-out floods from volcanogenic lakes in New Zealand. New Zealand Journal of Geology and Geophysics 50, 131-150.

25 Manville V, Swegschneider B, Newton E, et al. (2009) Environmental impact of the $1.8 \mathrm{ka}$ Taupo eruption, New Zealand: landscape responses to a large-scale explosive rhyolite eruption. Sedimentary Geology 220, 318-336.

26 McClelland E, Wilson CJN, Bardot L (2004) Paleotemperature determinations for the 1.8ka Taupo ignimbrite, New Zealand, and implications for the emplacement history of a high-velocity pyroclastic flow. Bulletin of Volcanology 66, 492-513.

27 McCraw JD (2011) The wandering river: landforms and geological history of the Hamilton Basin. Geoscience Society of New Zealand Guidebook 16, 1-88. 
28 Moebis A, Cronin SJ, Neall VE, et al. (2011) Unravelling a complex volcanic history from fine-grained, intricate Holocene ash sequences at the Tongariro Volcanic Centre, New Zealand. Quaternary International 246, 352-363.

29 New Zealand Forest Service (1980) Pureora State Forest Park Management Plan. New Zealand Forest Service, Auckland Conservancy, Auckland.

30 Nicholls J (1986) A descriptive overview of the central North Island volcanic upland. In Veale B and Innes JG (ed.), Ecological research in the central North Island volcanic plateau region. Forest Research Institute, Rotorua, pp. 2-17.

31 O'Loughlin C (1978) Hydrology of the Hauhungaroa Range state forests in relation to forest management practices. Management proposals for state forests of the Rangitoto and Hauhungaroa Ranges, central North Island, Taupo, 28-30 March 1978. New Zealand Forest Service, Wellington.

32 Selby MJ (1973) The erodibility of pumice soils of the North Island, New Zealand. Journal of Hydrology (NZ) 12, 32-56.

33 Selby MJ, Lowe DJ (1992) The middle Waikato Basin and hills. In Soons JM and Selby MJ (ed.), Landforms of New Zealand, 2nd edition. Longman Paul, Auckland, pp. 233-255.

34 Sherwood A, Edbrooke S (2015) Rocks that burn. In Graham IJ (ed.), A continent on the move, 2nd edition. Geoscience Society of New Zealand, Miscellaneous Publication 141, pp. 326-329.

35 Smith R, Lowe DJ, Wright I (2012) Volcanoes. Te Ara - the Encyclopedia of New Zealand http://www.TeAra.govt.nz/en/volcanoes, updated 9-Nov-12

36 Sutherland R, King P (2015) Leaving Gondwana behind. In Graham IJ (ed.), A continent on the move, 2nd edition. Geoscience Society of New Zealand, Miscellaneous Publication 141, pp. 130-131.

37 Thornton J (1985) Field guide to New Zealand geology. Reed Methuen, Auckland.

38 Townsend D, Vonk A, Kamp PJJ (2008) Geology of the Taranaki area: geological map 7, scale 1: 250,000. Institute of Geological and Nuclear Sciences, Lower Hutt.

39 Vandergoes MJ, Hogg AG, Lowe DJ, et al. (2013) A revised age for the Kawakawa/Oruanui tephra, a key marker for the Last Glacial Maximum in New Zealand. Quaternary Science Reviews 74, 170-194.

40 Walker A, Cooke R (2003) Waimiha: people of character. Waimiha Reunion 2001 Committee, Waimiha.

41 Walker G (1980) The Taupo pumice: product of the most powerful known (ultraplinian) eruption? Journal of Volcanology and Geothermal Research 8, 69-94.

42 Wilkes O, Gaukrodger J, Ritchie N (2011) Chronology of Pureora. Department of Conservation, Hamilton.

43 Wilmshurst JM, McGlone MS (1996) Forest disturbance in the central North Island, New Zealand, following the 1850 BP Taupo eruption. The Holocene 6, 399-411.

44 Wilson C, Leonard G (2015) Slumbering giants. In Graham IJ (ed.), A continent on the move, 2nd edition. Geoscience Society of New Zealand, Miscellaneous Publication 141, pp. 168-171.

45 Wilson CJN (1985) The Taupo eruption, New Zealand II. The Taupo ignimbrite. Philosophical Transactions of the Royal Society, London A 314, 229-310.

46 Wilson CJN, Walker GPL (1985) The Taupo eruption, New Zealand. I. General aspects. Philosophical Transactions of the Royal Society, London A 314, 199-228. 
47 Wilson CJN (1993) Stratigraphy, chronology, styles and dynamics of Late Quaternary eruptions from Taupo volcano, New Zealand. Philosophical Transactions of the Royal Society, London A 343, 205-306.

48 Wilson CJN (2001) The 26.5 ka Oruanui eruption, New Zealand: an introduction and overview. Journal of Volcanology and Geothermal Research 112, 133-174.

49 Wilson CJN (2008) Supereruptions and supervolcanoes: processes and products. Elements 4, 20-34.

50 Wilson CJN, Gravley DM, Leonard GS, et al. (2009) Volcanism in the central Taupo Volcanic Zone, New Zealand: tempo, styles and controls. In Thordarson T, Self S, Larsen G, Rowland SK and Hoskuldsson A (ed.), Studies in volcanology: the legacy of George Walker. Geological Society, London, Special Publications of IAVCEI 2, pp. 225-247.

51 Worthy TH, Holdaway RN (2002) The lost torld of the moa. Indiana University Press, Bloomington. 


\section{Box 1.1 Volcanic events and deposits in the central North Island}

Volcanic activity in the central North Island volcanic region (part of the Volcanic Plateau) has had a significant influence on the history and geography of PFP, and so some additional explanation of the more violent events and ensuing deposits may be helpful.

\section{Terminology}

Pureora, Titiraupenga, Ruapehu, and Tongariro are all cone volcanoes, which erupt generally andesitic to dacitic lavas and pyroclastic (fragmental) material derived from moderately viscous magma (molten rock) of intermediate silica content (52-69 wt\% $\mathrm{SiO}_{2}$ ). Numerous small effusive and explosive eruptions build a cone made up of both lava flows and pyroclastic deposits around a vent area.

Taupo is a rhyolite caldera volcano producing highly viscous and gas-rich rhyolitic magma rich in silica $\left(>69\right.$ wt\% $\mathrm{SiO}_{2}$ ). Rhyolitic eruptions are relatively infrequent but potentially very violent and explosive. Some (e.g., following the Oruanui and Taupo eruptions) were sufficiently voluminous to empty the underlying magma chamber and cause collapse of the ground surface, forming a caldera. Steep-sided rhyolite lava domes are commonly emplaced by effusive eruptions of de-gassed lavas following the explosive phase of rhyolite eruptions.

Tephra is a collective term (derived from a Greek word meaning 'ashes') for explosively erupted, loose, fragmental volcanic material that includes particles (pyroclasts) of different sizes, ranging from ash ( $<2 \mathrm{~mm}$ in diameter) and lapilli $(2-64 \mathrm{~mm}$ ), to blocks (angular) and bombs (rounded) (>64 $\mathrm{mm})$.

Pyroclastic flows are also known as lateral pyroclastic density currents (pyroclastic means literally 'fiery fragmental'), and are gravity-controlled, laterally-moving mixtures of pyroclasts and gas with high particle concentrations, generating deposits called ignimbrites.

Ignimbrites are typically rhyolitic in composition and contain glass shards, pumice pieces, crystals (mineral grains), and rock fragments (lithics) all buoyed and carried along by very hot gasses during their violent emplacement from fast-moving, ground-hugging density currents. The term ignimbrite literally means 'fiery storm-clouds', an apt term that reflects its violent mode of origin. Pyroclastic flows infill valleys forming extensive, thick sheets of fragmental rhyolitic material, and mount ridges forming thin veneer deposits. After deposition, thick, very hot $\left(600-700^{\circ} \mathrm{C}\right)$ deposits (such as those infilling valleys) can weld or sinter together to varying degrees of hardness. At one end of the hardness spectrum, some ignimbrites are rock solid (referred to as densely-welded ignimbrite), and at the other end, some can be excavated with a spoon (referred to as weakly welded). Others may be entirely non-welded: for example, Taupo ignimbrite and Oruanui ignimbrite are both non-welded ignimbrites (Smith et al. 2012) [35].

\section{Explosive eruptions and products: a summary}

More than a dozen ignimbrites were erupted from Mangakino caldera, referred to collectively as Pakaumanu Group (Briggs et al. 1993; Leonard et al. 2010) [3, 19]. Mangakino caldera has since been 
completely infilled by rhyolite lava domes. The ignimbrite cap on flat-topped Hikurangi is the Mangakino-derived Ongatiti ignimbrite, aged c. 1.23 Mya (Edbrooke 2005) 5].

Later, the large Whakamaru caldera, which lies north of Lake Taupo, erupted pyroclastic materials in an episode of intense volcanism, generating Whakamaru Group ignimbrites around 350,000 years ago. The Whakamaru 1 and 2 ignimbrites comprise about 1500 and $500 \mathrm{~km}^{3}$ of eruptive material (volumes are given as 'dense rock equivalent', DRE), respectively (Wilson et al. 2009) [50]. Both therefore qualify as products of so-called 'super-eruption' volcanic events (Wilson 2008) [49]. The Whakamaru ignimbrites are very extensive in the Pureora area (including much of the park), both west and east of Lake Taupo, and further north in the Tokoroa area (Leonard et al. 2010) [19].

The next major event was the Oruanui eruption, another 'super-eruption' episode at Taupo volcano, which generated about $530 \mathrm{~km}^{3}$ of material (DRE) or $1170 \mathrm{~km}^{3}$ as loose material (Wilson 2001) [48]. Also known as the Kawakawa eruption, the event is dated to c. 25,400 years ago (Vandergoes et al. 2013) [39]. The complex eruption produced a number of pyroclastic flow deposits, everywhere soft and non-welded (i.e. they comprise pumice clasts in a coarse ash matrix), known as Oruanui ignimbrite. In addition, fall deposits were blown at least $1500 \mathrm{~km}$ beyond the New Zealand archipelago. The Oruanui ignimbrite is found both to the northeast and southeast of the Pureora area, and it is extensive around the flanks of Taupo volcano (Leonard et al. 2010; Wilson 2001) [19, 48]. The Oruanui eruption was centred on the northern part of modern-day Lake Taupo (including Western Bay), and formed a large, 35-km-wide elliptical caldera forming the modern shape of the northern lake. The Waikato River, which for tens of millennia had flowed north across the Hauraki Plains into the Firth of Thames and beyond, was diverted westward into the Hamilton Basin around 22,000 years ago, partly because volcaniclastic debris from the Oruanui eruption washed down and eventually blocked the river at Piarere, near the junction of SH1 and SH 29 (Manville and Wilson 2004; McCraw 2011; Selby and Lowe 1992) 23, 27, 33].

Since the Oruanui/Kawakawa eruption, Taupo volcano has erupted a further 28 times, most recently as the so-called Taupo eruption (Wilson 1993; Wilson et al. 2009) [47, 50]. Rhyolitic ash materials from many of these 28 eruptions, and also equivalent distal deposits from rhyolitic eruptions in the Okataina Volcanic Centre near Rotorua, would have blanketed or 'dusted' the Pureora area when wind directions were suitable. At the same time, the andesitic volcanoes of Tongariro Volcanic Centre to the southeast of Pureora (Ruapehu, Ngauruhoe, Tongariro) have also been active, erupting very frequently since the earliest events dating back to c. 275,000 years ago (Lee et al. 2011) [17]. Multiple, thin, andesitic ash beds of varying thickness, often only a few millimetres or so, were frequently deposited on the Hauhungaroa and southern Rangitoto Ranges.

Several prominent andesitic ash-bed deposits of Holocene age (the Holocene comprises the past 11,700 years) derived from volcanoes in the Tongariro Volcanic Centre include the Mangamate tephra (erupted c. 11,200 years ago), Papakai tephra (c. 5000 years ago), and Mangatawai tephra (c. 3000 years ago). Occasionally, ash from Mt Taranaki (Egmont volcano), which began activity about 130,000 years ago (Townsend et al. 2008) [38], was blown as far east as Pureora and beyond, one recent thin bed being the Burrell ash (c. AD 1655) (Moebis et al. 2011) [28]. The most recent eruptions of the area (since the Taupo eruption), and their effects on Maori society, are summarised by Lowe et al. (2002) [21]. 


\section{Taupo eruption, its products and impacts}

The complex Taupo eruption sequence of $c$. AD 232 has been divided into seven phases. The products of each are described as subunits $Y 1$ to $Y 7$ of unit $Y$ by Wilson (Wilson 1993; Wilson and Walker 1985) $[46,47]$. The eruption was centred on vents near the now-submerged Horomatangi Reefs in the northeastern part of Lake Taupo (Fig. 1.3). Four eruptions of varying character and eruption style, generating Initial ash (subunit Y1), Hatepe plinian (Y2), Hatepe ash (Y3), and Rotongaio ash (Y4) took place, the wide variations relating to differences in discharge rate and the degree of interaction between the magma and water in proto-Lake Taupo and from rainstorms (Wilson 1985; Wilson and Walker 1985) [45, 46]. The fifth event in the sequence, Taupo plinian (Y5), generated a towering column of ash about 35 to $40 \mathrm{~km}$ high (Houghton et al. 2015 ) [14] comprising about $23 \mathrm{~km}^{3}$ of loose material. Ash from this plinian column was blown eastwards across the country well beyond Hawke's Bay and into the Pacific Ocean (Fig. 1.3). During this phase, minor intraplinian pyroclastic flows were generated near the vent area (Y6). The column then collapsed catastrophically to generate powerful ground-hugging pyroclastic flows (density currents) of hot gas, ash, pumice, crystals, and rock fragments that raced radially outward at speeds of more than 150 $\mathrm{m} / \mathrm{s}$ (200-300 m/s near the vent) to form the Taupo ignimbrite (Y7), containing at least $30 \mathrm{~km}^{3}$ of loose material (Wilson 1985) [45]. See Fig. 1.4.

The soft Taupo ignimbrite is non-welded, and was emplaced entirely within about 400 seconds (Wilson 1985) [45]. Its temperature was about $380-500^{\circ} \mathrm{C}$ at more than c. $40 \mathrm{~km}$ from vents; within c. $30-40 \mathrm{~km}$ of the vents it was about $150-300^{\circ} \mathrm{C}$ (Hudspith et al. 2010; McClelland et al. 2004) [15, 26]. The extreme violence of the emplacement of Taupo ignimbrite caused the deposit to be spread thinly over the landscape to an average thickness of only c. $1.5 \mathrm{~m}$, and the high energy release $(\geq 150$ \pm 50 megatons of TNT equivalent: Lowe and de Lange 2000) [20], enabled the Taupo ignimbrite to rush over hills and mountains up to c. $1500 \mathrm{~m}$ above the vent - no other pyroclastic flow is known to have climbed higher (Francis 1993) [6] - and the only mountain within its range that it did not ascend entirely was Ruapehu itself. That is why the beech trees on the southern and western slopes of Ruapehu were the only ones within $80 \mathrm{~km}$ of Taupo to escape complete destruction, and hence survived to spread and re-clothe the central volcanic mountains with beech forests similar to those that grew there before the eruption.

It is likely that this climactic ignimbrite-emplacement phase generated an atmospheric shock wave, producing a volcano-meteorological tsunami that reached coastal areas worldwide (Lowe and de Lange 2000) [20]. The total eruptive bulk (loose) volume for the Taupo eruptives has been estimated at c. $105 \mathrm{~km}^{3}$ (equivalent to c.35 $\mathrm{km}^{3}$ DRE) (Wilson et al. 2009) [50].

Following the Taupo eruption, Lake Taupo refilled and reached a higher level than today's, as is evident from the semi-continuous, wave-cut bench and highstand shoreline deposits (Manville et al. 1999; Manville et al. 2007) [22, 24]. Dramatic, sudden failure of a pumiceous pyroclastic dam led to the release of a peak discharge of $20,000-40,000 \mathrm{~m}^{3} / \mathrm{sec}$. Tonnes of loose pumice and other materials were washed down the Waikato River as a break-out flood event (Manville et al. 2007) [24], choking the river bed and depositing sediment many metres thick along the margins (Thornton 1985) [37]. 
Pre-existing sediments were cannibalised in part and transported as well as the mainly pumiceous materials. Temporary dams formed on the Ongarue River, followed by flash floods as the dams collapsed (Walker and Cooke 2003) [40]. Riparian terraces formed from the Taupo eruption-derived pumiceous alluvium (known geologically as Taupo Pumice Alluvium) are now common throughout many central North Island waterways (Manville et al. 2009; Nicholls 1986) [25, 30].

The violent emplacement of the Taupo ignimbrite devastated the forests, and charred logs as large as $1 \mathrm{~m}$ in diameter may be found in situ close to the vents (Froggatt et al. 1981) [7]. Hudspith et al. (2010) [15] estimated that about $1 \mathrm{~km}^{3}$ of forest timber was almost instantly incinerated.

The degree and nature of vegetation disturbance arising from the Taupo fallout deposits (rather than ignimbrite emplacement) varied according to the thickness of ashfall, local topographical features, and probably the vigour of the forest. Immediately after the eruption, stands of bracken and other seral taxa flourished. Revegetation was complete within about 200 years of the eruption, even at sites overwhelmed by the Taupo ignimbrite (Wilmshurst and McGlone 1996) [43].

\section{Explanation of Fig. 1.4 [Taupo eruption sequence)}

Products of most of the main phases of the eruption are shown here. Hatepe plinian, Hatepe ash, Rotongaio ash, and Taupo plinian are all fall deposits, comprising pyroclastic materials blasted into the air that were then blown by the wind to fall over the land surface like a blanketing snowfall. The characteristics of each unit relate in part to the rate of magma eruption and the amount of water entering the vent, so that the ensuing deposits range from coarse pumice clasts (open symbols), small rock fragments (closed symbols), and coarse to fine ash (fine stipple and dashes). The final deposit, Taupo ignimbrite, is the material that was spread across the landscape by the pyroclastic flow generated by the collapse of the towering plinian eruption column (Houghton et al. 2015; Wilson 1985) $[14,45]$.

The Hatepe ash phase of the eruption was abruptly terminated (possibly when lake water flooded deep into the vent), and running water from torrential rain carved gullies into the deposits (marked by ' $E$ ', indicating erosion by flowing water). After a break of less than about three weeks (Wilson 1993) [47], fine, dark-grey 'muddy' Rotongaio ash, and then pumices of the Taupo plinian phase, were deposited over the gullied landscape, forming the distinctive V-shaped pattern evident in the sequence. The emplacement of the Taupo ignimbrite generated another erosion surface (marked as ' $\mathrm{S}$ '), by shearing beneath the moving pyroclastic flow, resulting in a 'planed' or 'scalped' appearance to the top of the Rotongaio ash and Taupo plinian deposits (Houghton and Wilson 1986) [13] ). The section shown is on the western side of High Level Road in the Kaingaroa Forest about $1 \mathrm{~km}$ north of the Napier-Taupo highway.

\section{Box 1.2 Climate and soils of the Pureora area}

\section{Climate}

Over many years, the meteorological station at PFP Headquarters (NZMS station C85551, altitude $549 \mathrm{~m}$ ) returned data contributing to the calculations of climate normal for 1941-1970 (New Zealand Forest Service 1980; Hessell 1986) 10, 29]. Climate change since then gives these data considerable historical value. 
The central position of Pureora, well above sea level and far inland, gives it what meteorologists call a cool-temperate and damp climate. Pureora residents and visitors more often called it cold and wet, and NZFS managers were often faced with problems of maintaining relocatable buildings placed in a more severe climate than they were designed for.

The average annual temperature during $1941-70$ was $10.3^{\circ} \mathrm{C}$, ranging from $16^{\circ} \mathrm{C}$ in summer to $6^{\circ} \mathrm{C}$ in winter. Daily extremes ranged from $+30^{\circ} \mathrm{C}$ to $-9^{\circ} \mathrm{C}$. The lowest temperature ever recorded was $-17^{\circ} \mathrm{C}$ ("and I was there then", says ornithologist Rod Hay, pers. comm. 1986).

The slightly continental character of the climate is illustrated by the fact that the July mean temperature is about $2^{\circ}$ cooler than would be expected from the elevation alone. Ground frosts were recorded on an average of 87 days per year, at any season, and snow on two days a year.

The annual rainfall in Pureora village in 1941-70 averaged $1830 \mathrm{~mm}$, falling on 180 rain days (probably up to $2500 \mathrm{~mm}$ and on more days on the higher land). Wind flows were generally light, although occasional, very destructive, storms have been known. One storm, some time before 1915, uprooted countless hundreds of trees (Chap. 7). Another in 1958, well remembered by forest scientist Tony Beveridge when he was doing field work there, stripped heavy seed crops from rimu crowns, with serious consequences for seed-eating birds.

\section{Soils}

Most of the soils in the Pureora area are developed in pumice derived from the Taupo eruption event, notably the loose deposit of Taupo ignimbrite. Sequences of older tephra beds and buried soils are easily recognisable in cuttings and exposures, and river valleys are floored with soils derived from coarse pumice and ash deposits.

Over time the landscape has softened as the deep layers of tephra, eroded from higher ground and filling in the lower areas, gradually developed into infertile but usually free-draining soils. The tephra-derived soils generally become thicker eastwards, and are often composed of a thin layer of material derived from the Taupo eruption overlying sequences of older ash beds and associated, now-buried, soils called paleosols. These light, friable surface soils are very loose and easily eroded, and so as the landscape recovered from the eruptions, the regenerating forests played a crucial role in protecting the soils and reducing run-off into the rivers by helping to stabilise the landscape. Since then, any stripping of vegetation and litter and humified cover on the soil surface has always carried the risk of accelerated soil erosion, which would not only clog valley drainages but also cause excessive sedimentation in the cave systems of the Waitomo area (Leigh and Clegg 1989) [18] as well as degrading the soils themselves.

Fortunately, hill slopes in PFP are generally less than $30^{\circ}$ except in the steep-sided gullies, and the porous pumice soils seldom suffer from excessive run-off so long as they retain some vegetation (Selby 1973) [32].

Botanists are of course much more concerned about what vegetation remains, but for soil protection, anything with strong roots and deep litter will normally do the job. The hydrologist Colin O'Loughlin has concluded that forest management activities have had little effect on the important water resources of the region (O'Loughlin 1978) [31]. 